\title{
Correction to: Cohort profile: the Saskatchewan Rural Health Study—adult component
}

\author{
Punam Pahwa ${ }^{1,2^{*}}$, Masud Rana ${ }^{1}$, William Pickett ${ }^{3}$, Chandima P. Karunanayake ${ }^{1}$, Khalid Amin ${ }^{1}$, Niels Koehncke , \\ Valerie Elliot ${ }^{1}$, Louise Hagel ${ }^{1}$, Josh Lawson', Donna Rennie ${ }^{1,4}$, Shelley Kirychuk', Bonnie Janzen², Roland Dyck ${ }^{1}$ \\ and James Dosman ${ }^{1}$
}

\section{Correction to: BMC Res Notes (2017) 10:732}

https://doi.org/10.1186/s13104-017-3047-1

Following publication of the original article [1] the authors notified Production that the names of three authors-Valerie Elliot, Louise Hagel, and Roland Dyckhad been unintentionally omitted in the final online version of the manuscript. The corrected author list is shown in this Correction.

The authors also notified Production that the affiliations assigned to William Pickett are incorrect. The correct affiliation is reflected in the author list of this Correction.

\section{Author details}

${ }^{1}$ Canadian Centre for Health and Safety in Agriculture, University of Saskatchewan, 104 Clinic Place, PO Box 23, Saskatoon, SK S7N 2Z4, Canada. ${ }^{2}$ Department of Community Health and Epidemiology, University of Saskatchewan, Health Science Building, 107 Wiggins Road, Saskatoon, SK S7N 5E5, Canada. ${ }^{3}$ Department of Public Health Sciences, Queen's University, Carruthers Hall, Kingston, ON K7L 3N6, Canada. ${ }^{4}$ College of Nursing, University of Saskatchewan, 104 Clinic Place, Saskatoon, SK S7N 2Z4, Canada.

The original article can be found online at https://doi.org/10.1186/ s13104-017-3047-1.

\section{Publisher's Note \\ Springer Nature remains neutral with regard to jurisdictional claims in pub- lished maps and institutional affiliations.}

Received: 22 February 2018 Accepted: 22 February 2018

Published online: 26 March 2018

\section{Reference}

1. Pahwa P, Rana M, Pickett W, Karunanayake CP, Amin K, Koehncke N, Elliot V, Hagel L, Lawson J, Rennie D, Kirychuk S, Janzen B, Dyck R, Dosman J. Cohort profile: the Saskatchewan Rural Health Study-adult component. BMC Res Notes. 2017;10:732. https://doi.org/10.1186/s13104-017-3047-1.

${ }^{*}$ Correspondence: pup165@mail.usask.ca

${ }^{1}$ Canadian Centre for Health and Safety in Agriculture, University of Saskatchewan, 104 Clinic Place, PO Box 23, Saskatoon, SK S7N 2Z4, Canada

Full list of author information is available at the end of the article provided you give appropriate credit to the original author(s) and the source, provide a link to the Creative Commons license, and indicate if changes were made. The Creative Commons Public Domain Dedication waiver (http://creativecommons.org/ publicdomain/zero/1.0/) applies to the data made available in this article, unless otherwise stated. 